particular instances by an additional specialist designated by the Review Committee. The reports and recommendations of these representatives are forwarded to the Review Committee, along with other material prepared by the hospital, and the evaluation by the Committee thus represents the joint action of the Council, the Board, and in some cases the third national specialty organization. Depending upon the number of programmes in the various specialties, the related Review Committee meets from once to three times yearly for one or two days. All residency programmes are resurveyed normally at three-year intervals, but more frequently if the committee so directs.

The standards by which residency training programmes are organized, and against which they are evaluated by the Review Committees, are published by the Council as the Essentials of Approved Residencies. Often the Review Committees are the source of suggestions for revision of the "Essentials" for the specialty concerned. The "Essentials" agree closely with the published requirements of each of the specialty boards, and are included in the Directory of Approved Internships and Residencies, which is published annually and distributed to all hospitals in the United States and all medical schools throughout the world.

\section{Examination of Candidates}

After the resident has completed his training programme he is ready to apply for examination by the board in the specialty in which he is interested. In general, the conduct of examination by all boards is largely the same. Many divide their examinations into a Part I and a Part II. Usually the former is a written examination and the latter is oral. In most instances the essay type of examination has been abandoned in favour of one in which there are multiple choices. Thus answers can be brief-the "true-or-false type of examination." This type of examination is more expeditious ; it permits reports to be completed more quickly ; grading is more nearly accurate, and testing can be more extensive. As a rule the candidate becomes eligible for his oral examination after he has passed the "written." The oral examination varies with the requirements and needs of various specialties. It is important because it is the last obstacle to be surmounted before the candidate is certified.

Members of specialty boards are conscientious, honest, dedicated persons who contribute freely of their time and effort, often at great sacrifice, to advance the standards of their specialty, without thought of personal aggrandizement or recompense for their services. Like members of the faculty of a great university sitting at a defence of a doctoral dissertation, they are imbued with a sense of their responsibility to determine the competence of candidates who appear voluntarily before them for certification as diplomates.

Aside from setting up minimal standards which must be met before candidates can appear for examination before a board, such a board performs no function in the educational programme available for training future diplomates. It is the function of a specialty examining board to determine competence only and to certify those who possess it to a sufficient degree to warrant approbation. Somewhat like the dissociation between the judicial and the legislative branches of a modern democracy, a specialty examining board scrupulously avoids participation in that phase of the educational programme which aims at development of competency. Similarly, like a judicial body in and of itself, a specialty board has neither the will nor the authority to prevent the practice of any specialty by a licensed physician, regardless of his ability or lack of it. The chief objective of all specialty examining boards is to elevate and to maintain the standards of specialty practice, and the finite manifestation of their efforts toward this objective is the certificate of competence which they issue to all physicians who can meet minimal requirements of licensure and graduate medical education.

\title{
Hereditary Orotic Aciduria and Megaloblastic Anaemia: A Second Case, with Response to Uridine
}

\author{
D. M. O. BECROFT,* M.D. ; L. I. PHILLIPS, $\dagger$ M.B., CH.B., M.R.C.P., D.C.H.
}

Brit. med. F., 1965, 1, 547-552

Although orotic acid is an important precursor in the synthesis of pyrimidines (Figs. 1 and 6), only minute amounts are found in normal blood and urine (Smith and Baker, 1959 ; Lotz et al., 1963). The urinary excretion of large amounts of orotic acid was first reported by Huguley et al. (1959), occurring in a male child with a refractory megaloblastic anaemia.

Their patient was chronically ill with anaemia, repeated respiratory infections, and diarrhoea from the age of 3 months. Severe megaloblastic changes were found in several bonemarrow specimens, but there was no response to treatment with vitamin $\mathrm{B}_{12}$, folic acid, pyridoxine, ascorbic acid, and iron. Although adrenal steroids improved the anaemia, megaloblastosis was unaltered. Crystalluria had been noted and identification of the excreted material as orotic acid led to the suggestion that there was a congenital defect in the pathway of de novo

\footnotetext{
* Pathologist, Princess Mary Hospital for Children, Auckland, New Zealand.

† Children's Physician, Princess Mary Hospital for Children, Auckland, New Zealand.
}

synthesis of pyrimidine nucleotides. This conclusion was supported by the response obtained to the administration of the pyrimidine nucleotides, uridylic and cytidylic acids, contained in a yeast extract. The nucleotides, given at the age of 2 years 6 months, produced a striking clinical improvement accompanied by a haematological remission and marked reduction in orotic acid excretion. However, the yeast extract was poorly tolerated, relapse occurred, and the patient died from generalized varicella aged 2 years 9 months.

Huguley et al. could find no previous report of a similar case and we are not aware of any subsequent account. This report describes the clinical features of a child who is believed to have the same disease and his response to treatment with the pyrimidine nucleoside uridine.

\section{Case Report}

The patient was born on 26 October 1961, the delivery being normal. His birth weight was $9 \mathrm{lb} .2 \mathrm{oz}$. $(4,150 \mathrm{~g}$.). He was 
bottle-fed and sucked well. Initial weight gain was satisfactory. From about 3 months of age he was noted by his mother to be pale and to move and cry less than had her two older sons. At 1 year he made no effort to lift his head and shoulders and still did not sit unsupported. During this time he had no specific illnesses.

\section{OROTIC ACID}<smiles>O=C(O)c1cc(=O)[nH]c(=O)[nH]1</smiles>

\begin{tabular}{|l|c|c|}
\hline $\begin{array}{c}\text { PYRIMIDINE } \\
\text { (BASE) }\end{array}$ & $\begin{array}{c}\text { CORRESPONDING } \\
\text { NUCLEOSDE } \\
\text { (BASE+PENTOSE) }\end{array}$ & $\begin{array}{c}\text { CORRESPONDINC } \\
\text { NUCLEOTIDE } \\
\text { (BASE+PENTOSE+PHOSPHATE) }\end{array}$ \\
\hline OROTIC ACID & OROTIDINE & OROTIDYLIC ACID \\
URACIL & URIDINE & URIDYLIC ACID \\
CYTOSINE & CYTIDINE & CYTIDYLIC ACID \\
THYMINE & THYMIDINE & THYMIDYLIC ACID \\
\hline
\end{tabular}

Fig. 1.-Chemical formula of orotic acid and terminology used for pyrimidine derivatives.

In November 1962, when aged 13 months, he was admitted to Kawakawa Hospital, North Auckland, with bronchopneumonia, which responded to treatment with chloramphenicol. The haemoglobin was 4.6 g./100 ml. ; W.B.C. $2,400 / \mathrm{c} . \mathrm{mm}$. ; reticulocytes were less than $0.5 \%$ and platelets $220,000 / \mathrm{c} . \mathrm{mm}$. The red cells showed anisocytosis. The urine was said to be normal. He was transfused and given iron by mouth for one month, after which his haemoglobin was $6.4 \mathrm{~g} . / 100 \mathrm{ml}$.

When he was 14 months old he was transferred to Whangarei Hospital, North Auckland, for further investigation. At this time he was pale and nutrition was fair. He was lethargic, made minimal movements, but did reach for objects. He seemed withdrawn, had no speech, and was not sitting. He had a squint. There was no enlargement of liver, spleen, or lymph nodes.

Investigations at Whangarei Hospital.-Peripheral blood: haemoglobin 9.1 g./100 ml.; W.B.C. 3,300/c.mm. Bone-marrow aspiration: an active marrow with megaloblastic changes. Serum bilirubin $0.3 \mathrm{mg} . / 100 \mathrm{ml}$. ; Coombs test negative ; serum iron 11 $\mu \mathrm{g} . / 100 \mathrm{ml}$. Total non-protein nitrogen $40 \mathrm{mg} . / 100 \mathrm{ml}$; ; total plasma proteins 6.9 g. $/ 100 \mathrm{ml}$. (albumin $4.4 \mathrm{~g}$., globulin $2.5 \mathrm{~g}$.) ; serum alkaline phosphatase 15 King-Armstrong units; thymol turbicity 2.6 units; zinc sulphate flocculation negative; serum glutamic-oxalacetic acid transaminase 9 units; serum amylase 106 units $/ 100 \mathrm{ml}$. (Somogyi); serum calcium $10.4 \mathrm{mg} . / 100 \mathrm{ml}$. ; serum cholesterol $172 \mathrm{mg} . / 100 \mathrm{ml}$. $\mathrm{Kahn}$ and Laughlen tests negative; toxoplasmosis dye and complement-fixation tests negative. Urine: a trace of protein; no reducing substances detected; ferric-chloride test negative; no abnormality detected in deposit; no abnormal amino-acids. $X$-ray pictures of chest and skull and a barium meal were normal. Radiological bone age 12 months (chronological age 15 months).

Treatment at Whangarei Hospital.-In December 1962 he was given intramuscular iron (Imferon) $2 \mathrm{ml}$. daily for four consecutive days. There was no reticulocyte response although the serum iron increased to $85 \mu \mathrm{g} . / 100 \mathrm{ml}$. One week after iron was begun he was given folic acid, $20 \mathrm{mg}$. by intramuscular injection, followed by $15 \mathrm{mg}$. daily by mouth for the next eight weeks. Eight days after folic acid was started vitamin $B_{12}$ was given intramuscularly, $300 \mu \mathrm{g}$. as an initial dose followed by 11 injections of $100 \mu \mathrm{g}$. over the next two weeks. A gluten-free diet was begun in February 1963 and in the same month he was given pyridoxine $50 \mathrm{mg}$. daily for two weeks. A second bone-marrow examination still showed marked megaloblastic changes. Serum protein-bound iodine was low at $3 \mu \mathrm{g} . / 100 \mathrm{ml}$., and in March $1963 \mathrm{~L}$-thyroxine $100 \mu \mathrm{g}$. daily was given for one week. There was no reticulocyte response. He was then transferred to the Princess Mary Hospital for Children.

\section{Admission to Princess Mary Hospital}

On admission to our care at 1 year 5 months he weighed $21 \mathrm{lb}$. ( $9.5 \mathrm{~kg}$.) (below the third percentile). He was slightly pale and had an expressionless facies (Fig. 2a). There was an alternating strabismus. His hair was sparse, very short, and fine. He showed little interest in his surroundings, but did pick up and play with toys. He did not say words. He could not sit up, but was able to maintain a sitting position. There was no attempt to bear weight. Psychometric assessment indicated abilities within the 7- to 11months range. Head circumference was $18 \frac{1}{2}$ in. $(47 \mathrm{~cm}$.) Bloodpressure was $110 / 80 \mathrm{~mm}$. $\mathrm{Hg}$. The spleen was just palpable. There were no other abnormalities on physical examination, in particular no glossitis and no specific neurological findings.

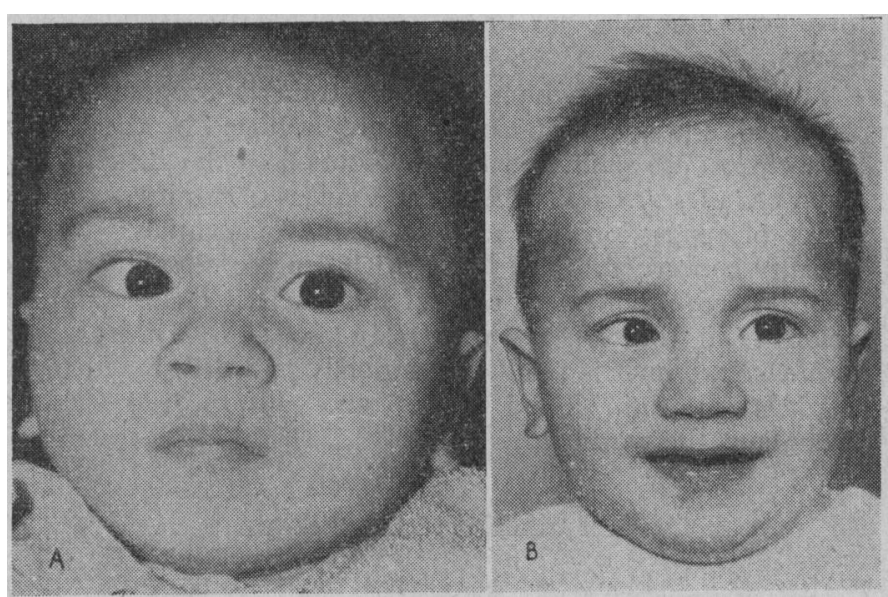

FIg. 2.- Hereditary orotic aciduria. (A) Patient aged 1 year 5 months, before uridine started. (B) Aged 2 years 9 months, after 14 months' treatment with uridine, showing hair growth

\section{Investigations}

Peripheral Blood.-Haemoglobin 8 g. $/ 100 \mathrm{ml}$; haematocrit $25 \%$; mean cell haemoglobin concentration $32 \%$; reticulocytes $2 \%$; E.S.R. $13 \mathrm{~mm}$. in one hour (Westergren); W.B.C. 5,000/ c.mm. (neutrophils $42 \%$, lymphocytes $52 \%$, monocytes $6 \%$ ). Film (Fig. 3a): The red cells showed a marked degree of anisocytosis and poikilocytosis. There were numerous macrocytes present, many strikingly large and oval in shape with long diameters up to $16 \mu$. Many macrocytes were hypochromic. Other cells were microcytic and irregular in shape. There were occasional polychromatic cells, stippled cells, Howell-Jolly bodies, Cabot's rings, and nucleated red cells, the latter showing megaloblastic features. Multisegmented neutrophils and giant platelets were present.

Bone-marrow.-The marrow obtained in February 1963 was reviewed. The marrow was cellular and there was a reversed myeloid-erythroid ratio of $1: 2$. Two-thirds of the nucleated red cells showed severe megaloblastic changes and there were numerous giant myelocytes and metamyelocytes.

Other Investigations.-There was a histamine-fast gastric achlorhydria. Serum vitamin $\mathrm{B}_{12} 580 \mu \mu \mathrm{g} . / \mathrm{ml}$. (normal 140 to 900 $\mu \mu \mathrm{g} . / \mathrm{ml}$.). Serum folic acid $28 \mathrm{~m} \mu \mathrm{g} . / \mathrm{ml}$. (normal 5.9 to 21 $\mathrm{m} \mu \mathrm{g} . / \mathrm{ml}$.). Direct Coombs test negative. Gregerson's test for faecal occult blood negative on two specimens. Serum levels of total proteins, albumin, globulin, calcium, phosphorus, and alkaline phosphatase were within the normal range. Urinary protein nil. Urinary deposit: W.B.C. 0-2/H.P.F. ; R.B.C. nil/H.P.F.

Urinary Orotic Acid.-The similarity of the case to that described by Huguley et al. (1959) led one of us (D. M. O. B.) to examine the urine for the presence of orotic acid. Urine specimens were clear when fresh, but on standing for several hours a large amount of

Urinary Orotic Acid Excretion

\begin{tabular}{|c|c|c|c|c|c|c|}
\hline \multirow{2}{*}{\multicolumn{4}{|c|}{ Therapy }} & \multirow{3}{*}{$\begin{array}{c}\begin{array}{c}\text { No. of } \\
\text { Specimens }\end{array} \\
6\end{array}$} & \multicolumn{2}{|c|}{ 24-hour Orotic Acid Excretion } \\
\hline & & & & & \multirow{2}{*}{$\begin{array}{l}\text { Range (g.) } \\
0.69-1.34\end{array}$} & \multirow{2}{*}{$\frac{\text { Mean (g.) }}{1 \cdot 15}$} \\
\hline Nil & .. & .. & .. & & & \\
\hline $\begin{array}{l}\text { Cytidylic } \\
\text { Uridine }\end{array}$ & $\begin{array}{l}\text { acid } 900 \\
\left\{\begin{array}{l}750 \mathrm{mg} \\
1,500 \mathrm{~m} \\
3,000 \mathrm{~m}\end{array}\right.\end{array}$ & $\begin{array}{l}\text { /day } \\
\text { day } \\
\text { day }\end{array}$ & $\begin{array}{l}\ldots \\
\ldots \\
.\end{array}$ & $\begin{array}{l}4 \\
3 \\
9 \\
1\end{array}$ & $\begin{array}{c}0.56-0.79 \\
0.49-0.95 \\
0.19=0.41 \\
-\end{array}$ & $\begin{array}{l}0.67 \\
0.74 \\
0.30 \\
0.20\end{array}$ \\
\hline
\end{tabular}


white flocculent precipitate developed. A feature of the deposit was the firm adherence of particles to the sides of glass containers. Microscopically the deposit consisted of colourless fine needleshaped crystals (Fig. 4). Identification of the deposit as orotic acid was confirmed by Dr. James A. Bain, Emory University School of Medicine, Atlanta, Ga., according to criteria previously published (Huguley et al., 1959). Quantitative estimations also were based on the method described by Huguley et al. The 24-hour excretion before treatment varied from 0.69 to $1.34 \mathrm{~g}$., with a mean of $1.15 \mathrm{~g}$. (see Table), and a concentration of 0.22 to $0.3 \mathrm{~g} . / 100 \mathrm{ml}$. No attempt was made to estimate orotic acid in blood.

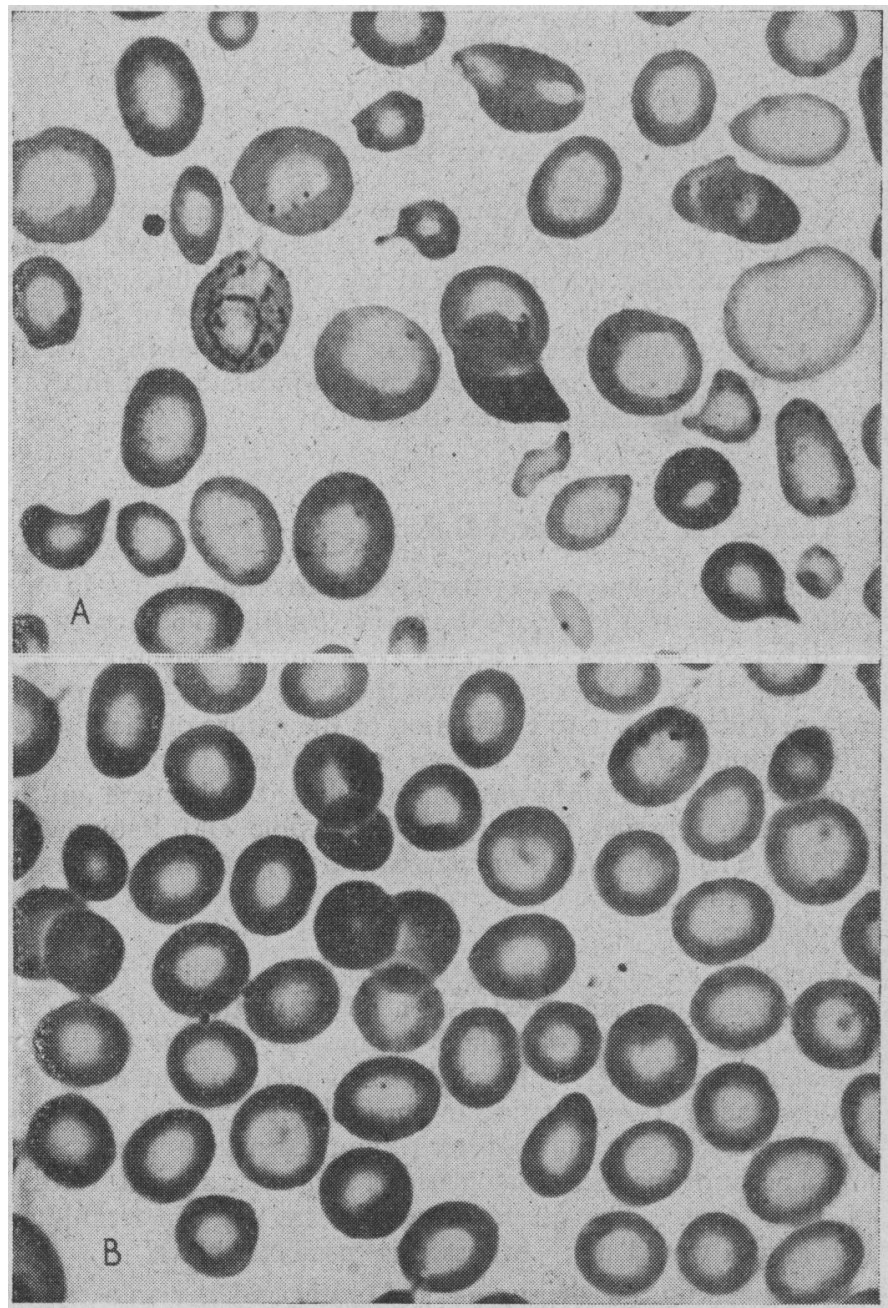

Fig. 3.-Peripheral blood. (A) Before treatment with uridine. (B) After six months' treatment with uridine. (Leishman. $\times 1,140$.)

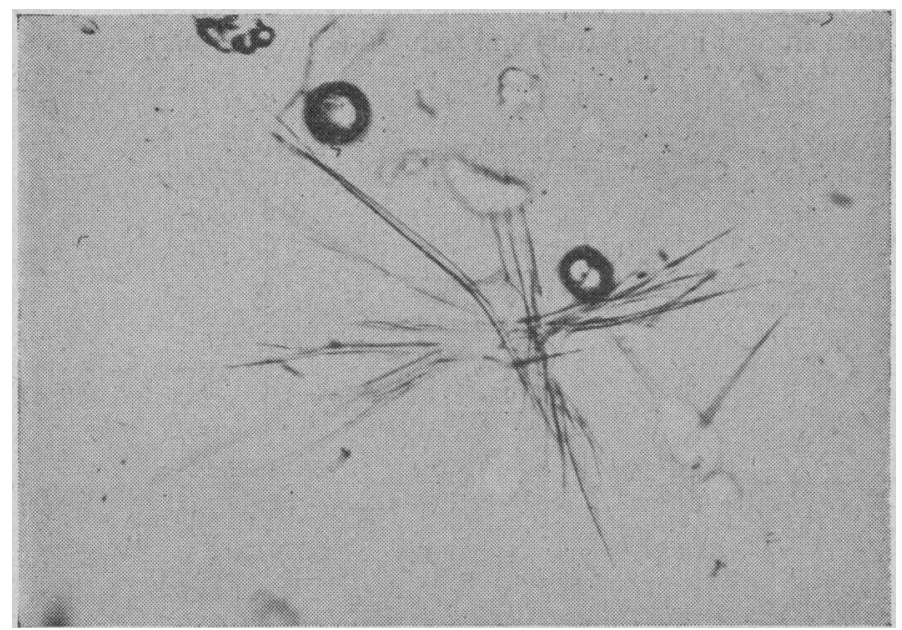

FIG. 4.-Orotic acid crystals in urine $(\times 515)$. The crystals in this stored specimen are slightly larger than in the fresh state.

\section{Initial Treatment (Fig. 5)}

During a preliminary five-week period of observation the haemoglobin remained between 7.6 and $8.8 \mathrm{~g} . / 100 \mathrm{ml}$. and the reticulocyte count between 2 and $3 \%$. Red-cell morphology remained markedly abnormal and a third bone-marrow aspiration on the day prior to beginning treatment confirmed that megaloblastosis persisted.

Cytidylic Acid.-The nucleoside uridine was selected as the agent for initial trial, but before this could be obtained $10 \mathrm{~g}$. of the nucleotide cytidylic acid became available. Cytidylic acid was given by mouth for 12 days, $900 \mathrm{mg}$. $(2.6 \mathrm{mMol}) /$ day divided into six 150-mg. doses. The treatment was complicated by an Escherichio coli enteritis on the sixth day, which resulted in dehydration and loss of weight. Otherwise his condition was unchanged and haematological response was slight. The maximum reticulocyte count was $3.2 \%$ on the fifth day and haemoglobin reached $10 \mathrm{~g}$./ $100 \mathrm{ml}$. on the twelfth day. There was no change in abnormal red-cell morphology. There was, however, an appreciable reduction in orotic acid excretion. Four 24-hour specimens collected during the 12-day period had a mean orotic acid content of $0.67 \mathrm{~g}$. $(58 \%$ of the pretreatment level). Ten days after discontinuing cytidylic acid orotic acid excretion had increased to $1.1 \mathrm{~g}$./day.

Uridine.-Treatment with the nucleoside uridine was begun in May 1963, at an initial dose of $150 \mathrm{mg}$. five times daily-that is, $750 \mathrm{mg}$. (3.1 mMol)/day. This dose of uridine was maintained for 11 days, again without marked haematological response. After 11 days the haemoglobin had increased from 8 to $9.4 \mathrm{~g} . / 100 \mathrm{ml}$., but there had been no reticulocyte response and red-cell morphology was unchanged. Orotic acid excretion again decreased, three 24-hour urine specimens having a mean content of $0.74 \mathrm{~g}$. (63\% of the pretreatment level). On the eleventh day the dose of uridine was doubled to $300 \mathrm{mg}$. five times daily, a total of $1,500 \mathrm{mg} . /$ day. There was a definite haematological response. The reticulocyte count increased to a maximum of $5.4 \%$ on the fifth day, then decreased to remain below $1 \%$ subsequently. By the twelf th day haemoglobin had increased to $11.3 \mathrm{~g} . / 100 \mathrm{ml}$. and remained above $11 \mathrm{~g} . / 100 \mathrm{ml}$ during succeeding weeks. The bone-marrow was examined on the seventeenth day of treatment at the higher-dose level and was now normal. Over several weeks the peripheral-blood film became near normal in appearance (Fig. 3b). The unusual hypochromic macrocytes disappeared but a small number of irregular microcytes persisted.

Accompanying the haematological remission there was an impressive clinical response. His colour, activity, and interest in his surroundings improved. Appetite increased markedly and there was a weight gain of $3 \mathrm{lb}$. (1,360 g.) in three weeks. Notably, there was a sudden spurt in the growth of his hair and nails, the latter requiring to be trimmed for the first time in six months.
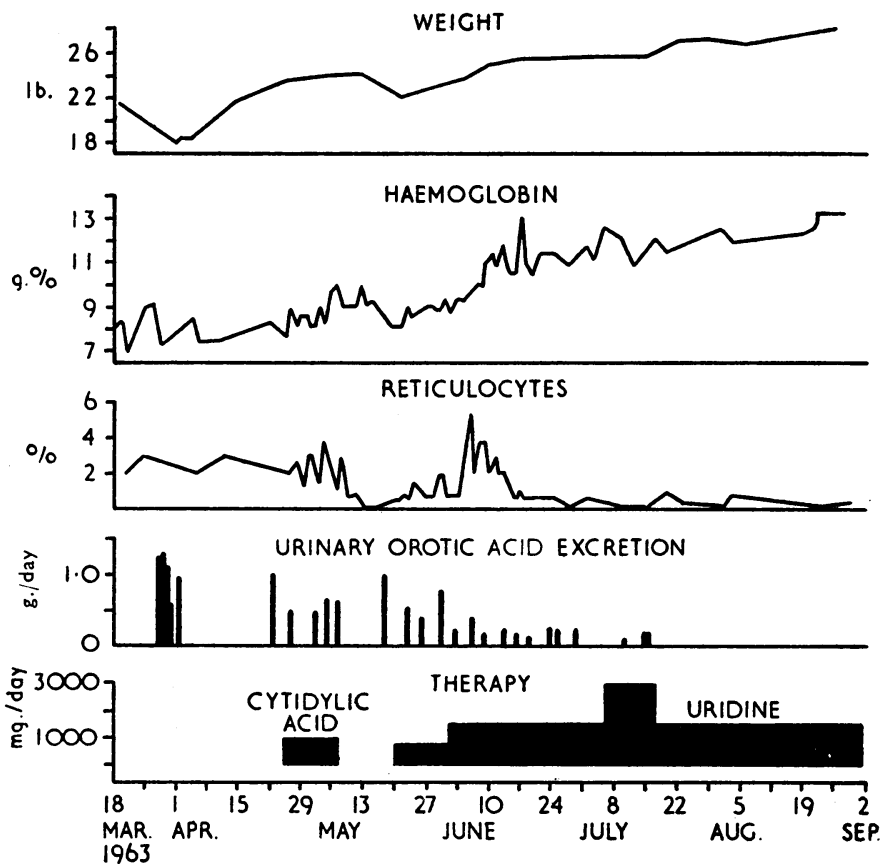

FIG. 5.-Changes in weight, haemoglobin, reticulocytes, and orotic acid excretion during the periods of observation and initial treatment. 
The higher dose of uridine further reduced orotic acid excretion. Nine 24-hour urine specimens were collected during the first month, in which $1,500 \mathrm{mg}$. of uridine was being given daily. Orotic acid excretion ranged from 0.19 to $0.41 \mathrm{~g}$./day, with a mean of $0.3 \mathrm{~g}$./ day $(26 \%$ of the pretreatment level). The dose of uridine was then doubled to $600 \mathrm{mg}$. five times daily to determine if excretion could be further depressed. There was no significant change by the eighth day, the urine still containing $0.2 \mathrm{~g}$. of orotic acid. After 10 days the dose of uridine was returned to $1,500 \mathrm{mg}$. daily, and this was continued for the next eight months.

\section{Subsequent Course}

He made steady progress in his development. After two months of effective treatment he began creeping on his abdomen and was able to stand holding his cot. Just before 2 years he began to feed himself by spoon. At 2 years 2 months he began to say single words. He walked unaided at 2 years 5 months.

Weight increased rapidly to $32 \frac{1}{2} \mathrm{lb}$. $(14.7 \mathrm{~kg}$.) after eight months' treatment-that is, from below the 3rd percentile to near the 90th percentile. His gain in height was less remarkable, reaching the 10th percentile at 2 years 4 months. Growth of hair and nails continued, although the hair remained short, sparse, and fine. Dental assessment at 2 years showed his teeth to be normal, apart from slight hypoplastic discoloration of the enamel.

His haemoglobin remained between 10 and $12 \mathrm{~g} . / 100 \mathrm{ml}$. After eight months' treatment macrocytes reappeared in the peripheral blood. A minority of erythroid cells in the bone-marrow were megaloblastic, although the appearances were not those of florid relapse. Because of the patient's rapid growth the dose of uridine, originally $150 \mathrm{mg} . / \mathrm{kg}$. body weight, now represented only $100 \mathrm{mg} . /$ kg., this being near the level previously found to be ineffective. The dose of uridine was increased to the former level of $150 \mathrm{mg} . / \mathrm{kg}$.that is, $750 \mathrm{mg}$. t.d.s. - and nine days later the bone-marrow had returned to normal. He remained well and was discharged from hospital in April 1964 aged 2 years 6 months. Fig. 2b shows hair growth at the age of 2 years 9 months, after 14 months' treatment.

At 3 years he was active and progressing well. There had been further growth of hair. His weight was at the 90th percentile and his height about the 50th percentile. He had abilities at the 2-yearold level. His peripheral blood was normal and orotic acid excretion was approximately $0.5 \mathrm{~g} . /$ day.

\section{Discussion}

This case has many features in common with that described by Huguley et al. (1959) (J.M.R.).

1. Megaloblastic Anaemia.-Both children were severely anaemic in early life and multiple bone-marrow examinations showed severe megaloblastic changes. The red cells were hypochromic although normal serum-iron levels were demonstrated in both children.

2. Resistance to Usual Therapy.-The megaloblastic state persisted after treatment with adequate amounts of vitamin $B_{12}$, folic acid, and pyridoxine. Normal serum levels of vitamin $\mathrm{B}_{12}$ and folic acid were confirmed in our patient.

3. Orotic Aciduria.-Before treatment J. M. R. excreted up to $1.5 \mathrm{~g}$. of orotic acid in 24 hours and our patient a maximum of $1.34 \mathrm{~g} . / 24$ hours. This excretion is approximately 1,000 times the average in normal adults (Lotz et al., 1963). Freshly voided urines were clear, but a heavy deposit appeared on standing. At no time has our patient had symptoms of obstruction in the urinary tract similar to those suffered by J.M.R. when oliguric. During remission the orotic acid excretion fell to less than one-quarter of previous levels.
4. Physical and Mental Retardation.-Both children were considerably underweight, our patient being below the $3 \mathrm{rd}$ percentile prior to treatment. Activity was subnormal and there was a significant degree of intellectual impairment in both cases.

5. Response to Pyrimidine Derivatives.-Our patient responded to the pyrimidine nucleoside, uridine; J.M.R. responded to a mixture of the pyrimidine nucleotides, uridylic and cytidylic acids. Doses were similar-that is, $6.2 \mathrm{mMol}$ and $5 \mathrm{mMol}$. The response of our patient to a suboptimal dose of cytidylic acid suggested that a larger dose would have been effective. In both children haematological remission was accompanied by an immediate increase in appetite, weight gain, activity, and intellectual ability.

\section{Points of Difference Between the two Cases}

Gastro-intestinal symptoms were never prominent in our patient, whereas J.M. R. suffered persistent diarrhoea. Both children had gastric achlorhydria, but this was histamine-fast in our patient and not in J.M.R. The deficiency of hair and nail growth prominent in our patient was not noted in J. M. R., but the renewal of growth with remission indicates that this was a further manifestation of the disease.

\section{Nature of the Biochemical Defect}

Megaloblastic anaemia is uncommon in infancy, but in our patient most of the accepted causes (Smith, 1960) could be excluded on the basis of history, relevant investigations, and failure of response to conventional therapy. Excretion of orotic acid provides the key to elucidation of the nature of the disease. The position of orotic acid as an intermediary in the de novo synthesis of pyrimidines was first established in bacteria and in some animal tissues (Carter, 1956; Hepple and Rabinowitz, 1958). The pathway summarized in Fig. 6 was generally assumed to be that responsible for the net synthesis of pyrimidines.

Huguley et al. (1959), assuming that similar pathways operated in man, suggested that a defect in either of the two sequential enzymes orotidylic pyrophosphorylase or orotidylic decarboxylase could result in the accumulation and excretion of orotic acid. The reduction in pyrimidine nucleotide synthesis through effects on nucleoprotein and coenzyme metabolism could account for the megaloblastosis and other clinical features of their case. The effect of administration of pyrimidine nucleotides would be to bypass this metabolic block.

Confirmation that the synthesis of orotic acid in man occurred through similar pathways was obtained after the death of J.M. R. (Smith and Baker, 1959). The two suspect enzymes, orotidylic pyrophosphorylase and orotidylic decarboxylase, were then studied in his family and reduced activity of both enzymes

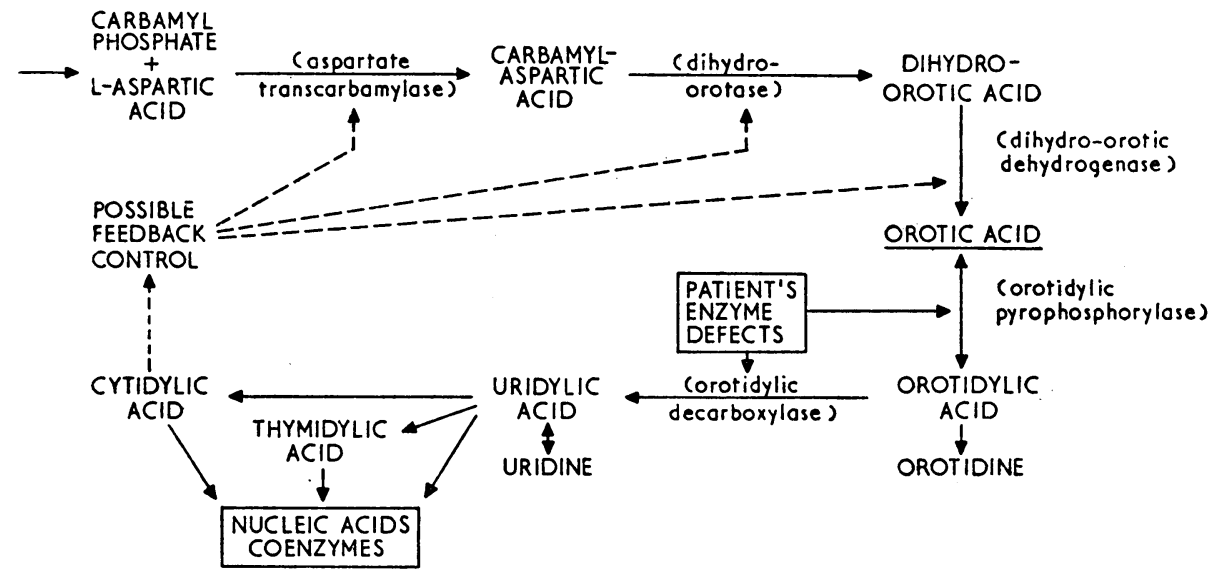

FIG. 6.-Summary of pathway of de novo synthesis of pyrimidines (after Huguley and Bain, 1960). 
was found in the erythrocytes of the parents and two of the three siblings (Smith et al., 1961 ; Fallon et al., 1962). The results for orotidylic decarboxylase were confirmed in leucocytes, but these cells were unsatisfactory for assay of pyrophosphorylase. The results strongly suggested that the parents and the two siblings were heterozygous for an autosomal recessive trait, which in the homozygous state would be characterized by further reduction or absence of these two enzymes.

Our patient has provided the first opportunity for study of the presumed homozygous state using these techniques. Additional information has been gained from his response to treatment.

Therapeutic Approach.-Reference to Fig. 6 indicates the relevance of determining the effect of administration of orotidylic acid or orotidine, as a response to either would imply significant activity of orotidylic decarboxylase. Unfortunately, the cost of giving the theoretically effective dose of each is prohibitive, and, furthermore, it is likely that parenteral administration would be required. Either of the nucleotides, uridylic acid or cytidylic acid, probably would have been effective, but the nucleoside uridine was preferred on the grounds of being substantially cheaper, and, by analogy with other mammalian systems, presumably convertible to uridylic acid in vivo. The response obtained with uridine confirms that this material can be utilized, but does not contribute further information on the basic enzyme defect. Suppression of orotic acid excretion during remission parallels the finding in the previous case and supports the suggestion of Huguley et al. that there might be a negative feed-back control on pyrimidine biosynthesis (Fig. 6), similar to that which has been demonstrated in bacterial systems (Yates and Pardee, 1956).

\section{Other Biochemical Investigations}

These have been carried out at several centres in the United States and only preliminary results are reported here.

1. Enzyme Studies (Smith et al., 1964).-No activity of orotidylic pyrophosphorylase and orotidylic decarboxylase was detected in red cells from our patient during relapse and in remission. There was no decarboxylase activity demonstrable in leucocytes, but pyrophosphorylase estimations were unsatisfactory in these cells. Conversely, increased activity of two enzymes earlier in the pathway, aspartate transcarbamylase and dihydroorotase, was found in the red cells prior to treatment. These enzymes returned to normal during remission.

2. Urinary Metabolites (Bain and Huguley, to be published).-The presence of orotic acid was confirmed and increased excretion of two orotic acid precursors, carbamyl aspartic acid and dihydroorotic acid, was demonstrated. Orotidine was present at approximately 5 to 10 times the normal level.

3. Tissue Cultures (Howell, Klinenberg, and Krooth, to be published).-A satisfactory diploid-cell line has been established in tissue culture from a skin biopsy taken from our patient using methods previously described (Krooth and Weiberg, 1961 ; Krooth et al., 1962). Preliminary experiments have revealed grossly reduced levels of both orotidylic decarboxylase and orotidylic pyrophosphorylase in these cultured cells. The addition of either cytidine or uridine to the medium greatly stimulates cell growth.

Conclusions.-These preliminary results confirm the previous suggestion of a homozygous state characterized by defects in two enzymes in the pyrimidine pathway. There is, however, evidence for some activity of both enzymes, although at greatly reduced levels. Studies ir tissue culture showed detectable levels of orotidylic decarboxylase. A small amount of pyrophosphorylase activity is suggested by the finding in the urine of orotidine, presumably derived from orotidylic acid.
Increased activity of enzymes earlier in the pathway of pyrimidine synthesis and return to normal during treatment gives direct evidence for the existence of a feed-back controlling mechanism. This increased enzyme activity correlates with an increased excretion of precursors of orotic acid and with the fact that the daily excretion of orotic acid by the homozygotes exceeds estimates of the normal rate of pyrimidine synthesis (Weissman et al., 1962). In the presence of a near complete block in the major pathway of pyrimidine synthesis even marginal survival is surprising, and alternative metabolic pathways may be present.

An "Operon" Disease?-The results obtained in this case appear to confirm an apparent exception to the one gene/one enzyme hypothesis (Smith and Lotz, 1963). Recent hypotheses concerning the control of enzyme activity offer the theoretical possibility that the basis of the disease could be deletion of a single "operator" gene controlling the defective enzyme sequence (Jacob and Monod, 1961; Monod et al., 1963). However, it remains to be demonstrated that the enzyme sequence is a functional unit or "operon" under the control of such a gene.

Acquired Orotic Aciduria.-The antineoplastic agent 6-azauridine is a specific competitive inhibitor of orotidylic decarboxylase and produces an acquired and reversible orotic aciduria (Fallon et al., 1962 ; Lotz et al., 1963). Elves et al. (1963) examined the chromosomes of dividing leucocytes from patients treated with 6-azauridine and observed a number of abnormal "globule" chromosomes which, it was suggested, were due to faulty synthesis of nucleic acids. A similar phenomenon was looked for in our patient but could not be detected in the pretreatment bone-marrow following short-term incubation with colchicine.

\section{Family Studies}

Investigation of parents and siblings of J. M. R. had indicated a heterozygous state without clinical abnormality, but with diminished enzyme activities, a minimal increase in urinary orotic acid excretion, and probably a decreased ability to metabolize a load of orotic acid (Smith et al., 1961; Fallon et al., 1962 ; Lotz et al., 1963). . Eighteen presumed heterozygotes were detected in a study of 63 members of the affected family (Fallon et al., 1964).

The parents of our patient are healthy. The father is Irish, the mother is a three-quarter caste Maori, and the possibility of consanguinity is remote. One older sibling is well. The other had an arrested hydrocephalus and died from a subdural haemorrhage after a fall. Recently the mother has given birth to a healthy boy, a half-brother to our patient.

The activity of orotidylic decarboxylase and pyrophosphorylase in the father's red cells was found to be decreased to levels similar to those previously found in heterozygotes. No orotic acid has been demonstrated in the urine of the mother, the eldest sibling, or the half-brother using methods sensitive to approximately $1 \mathrm{mg} . / 100 \mathrm{ml}$.

\section{Prognosis}

Our patient has made substantial progress in the 18 months of uridine therapy. This progress is continuing, but it appears probable that there will be some permanent intellectual retardation. The prompt response suggests that had treatment been begun soon after birth normal intellectual development might have been achieved. Hereditary orotic aciduria can thus be grouped with those inborn errors of metabolism in which early diagnosis and a treatment are essential for normal development. Although extremely rare, the disease should be suspected in any child with megaloblastic anaemia, with unexplairied crystalluria, or when mental retardation and anaemia coexist. Treatment of 
hereditary orotic aciduria is not difficult in principle, using small amounts of a palatable soluble chemical given by mouth and free of side-effects. Observation of the peripheral blood should be sufficient to control dosage, supplemented when necessary by bone-marrow examinations and estimations of orotic acid excretion. Through the generosity of Nutritional Biochemicals Corp., Cleveland, Ohio, uridine is at present supplied at a cost which is reasonable in comparison with that of treating many chronic diseases. The treatment of orotic aciduria detected in early infancy promises to be simple, economic, and rewarding.

\section{Summary}

A second case of hereditary orotic aciduria is described. This diagnosis was established in a 17-month-old boy with megaloblastic anaemia who failed to respond to treatment with vitamin $\mathrm{B}_{12}$, folic acid, pyridoxine, and thyroxine. He was found to excrete more than $1 \mathrm{~g}$. of orotic acid daily.

Preliminary results of biochemical studies support the previous hypothesis that this is an inborn error of pyrimidine metabolism in which there is marked reduction in activity of two sequential enzymes in the major pathway of pyrimidine synthesis. This is transmitted as an autosomal recessive trait.

Haematological remission was induced by the nucleoside uridine and has been maintained for 18 months. Previous physical and mental retardation has responded to treatment, although some degree of intellectual impairment is likely to persist. The likelihood of gratifying results from early diagnosis and treatment of this disease is emphasized.

We should like to thank Dr. G. T. Fox, senior paediatrician, for permission to publish this case. We are indebted to Dr. Charles $M$. Huguley, jun., and Dr. Lloyd H. Smith, jun., for advice on the management of the case ; to Drs. Huguley, Smith, and Robert S. Krooth for permission to include preliminary results of their investigations; to Dr. F. H. Sims, Dr. R. K. Ralph, and Miss Anne Simmonds for chemical investigations; to Dr. J. M. Staveley, haematologist, Auckland Hospital, for opinions on bone-marrow specimens; to Dr. D. M. G. Beasley, paediatrician, Whangarei Hospital, for information on the early course of the patient; to Dr. J. M. Costello and Miss M. Blackwell for psychometric assessments ; and to Sister H. J. Smyth for nursing care.

\section{REFERENCES}

Carter, C. E. (1956). Ann. Rev. Biochem., 25, 123 .
Elves, M. W., Buttoo, A. S., Israels, M. C. G., and Wilkinson, J. F. (1963). Brit. med. F., 1, 156.

Fallon, H. J., Lotz, M., and Smith, L. H., jun. (1962). Blood, 20, 700. Smith, L. H., jun., Graham, J. B., and Burnett, C. H. (1964). New Engl. ₹. Med., 270, 878.

Hepple, L. A., and Rabinowitz, J. C. (1958). Ann. Rev. Biochem., 27, 613.

Huguley, C. M., jun., and Bain, J. A. (1960). In The Metabolic Basis of Inherited Disease, edited by J. B. Stanbury, J. B. Wyngaarden, and D. S. Fredrickson, p. 776. McGraw-Hill, New York.

Rivers, S. L., and Scoggins, R. B. (1959). Blood, 14, 615.

Jacob, F., and Monod, J. (1961). 7. molec. Biol, 3, 318.

Krooth, R. S., Howell, R. R., and Hamilton, H. B. (1962). F. exp. Med., 115,313 .

and Weinberg, A. N. (1961). Ibid., 113, 1155.

Lotz, M., Fallon, H. J., and Smith, L. H., jun. (1963). Nature (Lond.), 197, 194.

Monod, J., Changeux, J. P., and Jacob, F. (1963). F. molec. Biol., 6,

Smith, C. H. (1960). Blood Diseases of Infancy and Childhood. Mosby, St. Louis.

Smith, L. H., jun., and Baker, F. A. (1959). 7. clin. Invest., 38, 798. - Huguley, C. M., jun., and Bain, J. A. (1964). In The Metabolic

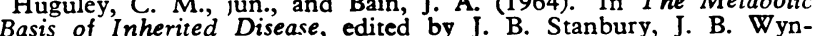
Basis of Inherited Disease, edited by gaarden, and D. S. Fredrickson, 2nd ed. McGraw-Hil

Sullivan, M., and Huguley, C. M., jun. (1961). F. clin. Invest., 40, 656.

Weissman, S. M., Eisen, A. Z., Fallon, H., Lewis, M., and Karon, M. (1962). Ibid., 41, 1546 .

Yates, R. A., and Pardee, A. B. (1956). F. biol. Chem., 221, 757.

\title{
Hypocholesterolaemia and Orotic Aciduria During Treatment with 6-Azauridine
}

\author{
A. S. BUTTOO,* M.D. ; M. C. G. ISRAËLS,* M.D., M.SC., F.R.C.P. ; \\ JOHN F. WILKINSON,* M.D., M.SC., PH.D., F.R.C.P., F.R.I.C.
}

Brit. med. F., 1965, 1, 552-554

The pyrimidine analogue 6-azauridine (6-AzUR) has been used in the experimental treatment of leukaemia (Wilkinson, 1963, 1964). It is a moderately potent antileukaemic drug, free from serious toxicity, which exhibits some unusual and interesting side-effects. The urinary excretion of large quantities of orotidine and orotic acid demonstrates the drug's interference with the de novo synthesis of pyrimidine nucleotides (Handschumacher et al., 1960a), which is also reflected in the chromosomal changes seen in the leucocytes of leukaemic patients treated with 6-AzUR (Elves et al., 1963). Another effect, noted by Fallon et al. (1961), is an increased uric-acid clearance.

6-AzUR therapy may result in the appearance of megaloblastic changes in the marrow, presumably due to inhibition of orotidylic decarboxylase. An increased plasma clearance of intravenously injected folic acid and urinary excretion of formiminoglutamic acid following a histidine load have also

* Department of Clinical Haematology, University and Royal Infirmary, Manchester. been noted (unpublished observation). We are reporting hcre a hitherto undescribed side-effect of 6-AzUR therapynamely, the depression of serum-cholesterol levels.

This finding was noticed during the performance of liverfunction tests to exclude hepatotoxicity of 6-AzUR. The importance of this finding lies in the fact that 6-AzUR is perhaps the only substance available at the present moment that appears capable of affecting both the nucleic acid and the lipid metabolisms. Besides affording exciting possibilities for future investigations, this property of 6-AzUR has a potential value in the lowering of the plasma-cholesterol level in clinical medicine. Apart from hypocholesterolaemia, 6-AzUR did not induce any other abnormality in the liver-function tests.

\section{Methods}

Clinical Studies.-Five patients with various types of acute leukaemia, one patient with lymphosarcoma, and another with multiple myeloma were each given $10 \mathrm{~g}$. daily of $6-\mathrm{AzUR}$ by a 